Science Life

\title{
THE EUROPEAN ACADEMY OF SCIENCES AND ARTS IN THE BALTIC
}

\author{
Jānis Stradiṇš and Anita Draveniece \\ Latvian Academy of Sciences, Akadēmijas lauk. 1, Rīga, LV-1524, LATVIA
}

\begin{abstract}
Alongside ordinary national academies of sciences, which are the highest national autonomous institutions of science in a country, there are also transnational academies of sciences, or unions of academies. The European Academy of Sciences and Arts (EASA) - Academia Scientiarum et Artium Europaea (seated in Salzburg) - is not an ordinary academy of sciences. To the wider academic community, it has acquired the unofficial name of "Unger's Academy", which came from the name of the academy founder and president, heart surgeon Felix Unger. The EASA was established on 7 March 1990, and this year it celebrated the $20^{\text {th }}$ anniversary.
\end{abstract}

Indeed, Unger's Academy is a distinctive body: it is not a "classical" academy of sciences that encourages and promotes exact, basic sciences and research, but it is the watch tower of European basic values - science, religion and philosophy. Its mission is to contribute to the future of Europe and its unity by promoting knowledge, cooperation and tolerance.

The Academy was taking shape at the time, when the wall between the Eastern and Western Europe fell, alongside the collapse of the socialist camp, the Soviet Union and Tito's Yugoslavia. Also, far-reaching changes had started in the Catholic Church - modernisation and dialogue with science and other confessions (this process actually started well before the pontificate of Pope John Paul II, and as early as during the pontificate of Pope John XXIII and even that of Pope Paul VI, after the Vatican Council in 1962-1965. In Austria, fresh ideas emerged about Austrian identity and reminiscences of the Holy Roman Empire, based in Vienna, and of the emperor Charles the Great, crowned in Aachen. The idea of a Pan-Europe acquired interest and intentions emerged to bring closer Western Europe and Eastern and Southern Europe, which were for a long time disunited politically, ideologically and in understanding of basic values.

Against that background, then a still young and ambitious Austrian heart surgeon Felix Unger (born in 1943), graduate of the University of Vienna (1971), a Fullbright Scholar (1975) and the chairman (since 1985) of the Department of Cardiac Surgery at the Paracelsus Medical University in Salzburg, together with Austria's Cardinal Franz Koening (who was very close to Pope John XXIII) and Nikolaus Lobkowicz, professor of the philosophy of religion, established a new, unofficial academy of sciences and brought together more persons who shared their views. The Academy has gained international recognition and at present there are 1300 members representing most European countries and also countries all over the world (altogether 58). The Academy membership includes more than 20 Nobel laureates (including Mikhail Gorbachev, former president of the Soviet Union), and also, what is quite unusual for an academy of sciences, the current Pope Benedict XVI was elected to the membership in 1992 as Cardinal Joseph Ratzinger.

The European Academy of Sciences and Arts names protectors - heads of state who have undertaken to support science and art in their respective countries. Currently, among the protectors of the EASA are such eminent persons as the presidents of the Republic of Austria and the Slovak Republic, the King of Spain Juan Carloss I, Crown Prince Philip of Belgium, the Grand Duke of Luxembourg, the presidents of Greece and Slovenia, and since October 2009 the president of Latvia V. Zatlers. In the past, the title of protector has been awarded to such distinguished statesmen as H. Kohl, A. Göncz, H.D. Genscher, V. Havel, C. Ciampi, J. Santer, R. Prodi, M. Kucan, G. Verhofstadt and also V. Vike-Freiberga, former president of the Republic of Latvia. After the expiry of the term of office as president he/she remains a honorary senator of the European academy of Sciences and Arts. The current president of the European Parliament J. Buzek also is the member of the EASA.

Unger's Academy was among the first foreign academies of sciences to establish official contacts with the Latvian Academy of Sciences (LAS) on 13 April 1991, even before the restoration of Latvia's independence in August of that year. Felix Unger visited Rīga at his personal initiative. Professor Unger's both moral and financial support made it possible to organize in Riga the first congress of cardiac surgeons of the Baltic Sea states in 1993 in the same year the European-Latvian Institute for Cultural and Scientific Exchange „Eurolat” was established in Rīga (the first curators were J. Stradiņš and U. Viesturs, the scientific secretary was Dr. M. Jākobsons, 1993-1998, afterwards Dr. A. Dra- 


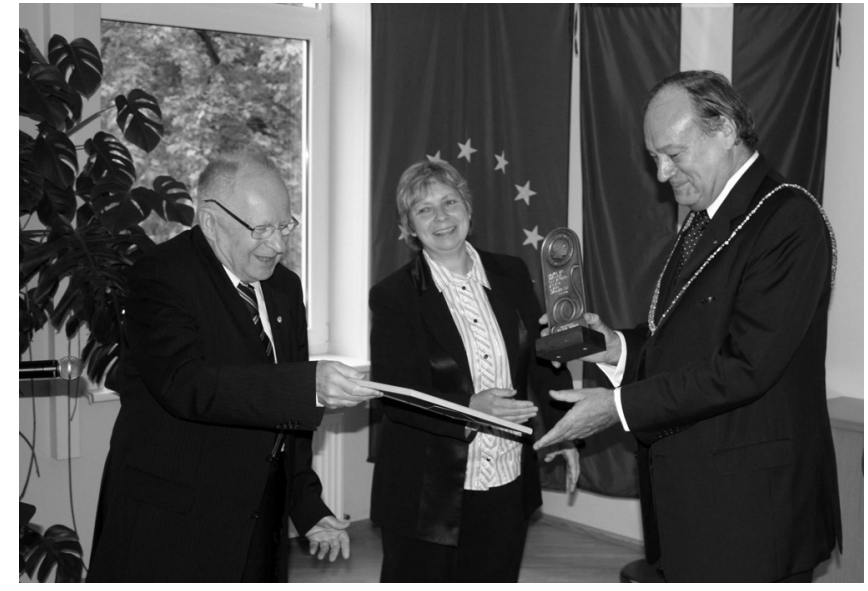

Professor Felix Unger (right) receiving the Pauls Stradiņš Prize out of the hands of Professor Jānis Stradiņš (left) at the presence of Mrs. Edìte Bērzina, director of Pauls Stradinš Museum for History of Medicine, on 15 October 2009. The prize includes a statuette and a diploma.

veniece, 1998- present). Upon recommendation of Professor Unger, the first members from Latvia were elected to the EASA: physicist J. Lielpēters, J. Stradiņš, U. Viesturs, heart surgeon J. Volkolākovs, physicist E. Blūms, and biologist R. Kondratovičs. When, in 1993, the first members were elected to the EASA, the Latvian Delegation of the EASA began taking shape and J. Stradiňš was nominated as the head or ambasssador of the delegation. In later years, historian A. Caune, biomechanist I. Knēts, physicist, LAS president J. Ekmanis, chemist T. Millers, philosopher M. Kūle, physician J. Vētra, demographer P. Zvidriňš, pharmacologist V. Kluša and lawyer and politologist T. Jundzis became members of the EASA, and presidents of Latvia V. Vīke-Freiberga (in 2000) and V. Zatlers (2009) were named the protectors of the Academy. Recently we have recommended for EASA membership heart surgeon R. Lācis, art scholar I. Lancmanis and rector of the Art Academy S. Naumovs.

The EASA includes several members from Lithuania (J. Antanavičius, B. Juodka, J. Požela, A. Praškevičius) and even more from Estonia (H. Aben, J. Arrak, J. Engelbrecht, K. Haller, A.E. Kaasik, J. Kalda, A. Krikmann, N. Kristoffel, E. Oja, T. Paul, T.-A. Sulling, T. Tiivel, P. Tulviste, J. Undusk).

Felix Unger, in January 1992, was elected foreign member of the LAS and, in 2003, he was conferred the degree of honorary doctor of Rīga Stradiňš University. In 2009, he was awarded the Pauls Stradiņš Prize for founding the EASA and for continued generous support to Latvian science.

What makes Latvia so interesting to professor Unger, and why does he have sympathies for Latvia? Indeed, we have a close personal relationship since 1991, when professor Unger visited Latvia for the first time and we organised for him tours to Vidzeme, but the true motive behind his deep interest is as follows. Felix Unger's family history reaches back to medieval Livonia, to the families of von Lieven's and the Ungern-Sternbergs. Felix Unger is a direct, but far-off descendant of Kaupo, the Liv chieftain, whose name is well-known in Latvia's history. It may be possible that in his face we can notice some facial features of Livs. The elder daughter of Kaupo was married to knight Johan von Sternberg, who was nicknamed Ungārs (Unger), as he had come from Hungary (Ungārija). In medieval times, the von Lievens owned Turaida and Krimulda, and descendents of Kaupo daughter's (Ungerns) owned Madliena, Aderkaši, Meņgele and Ogre district. Interestingly, the name Madliena was coined by Ungers' ancestor in commemoration of his sister-in-law (Magdalena), the youngest and unmarried daughter of Kaupo. In this place (Madliena) the Magdalena church was built in honor of Magdalena who was regarded as a saint in medieval Livonia. Professor Felix Unger belongs to the Sternberg family branch of the Ungern, who moved from Livonia to Austria in Central Europe. The reason for the move was that, during the Age of Reformation, they remained faithful to Catholicism and did not wish to convert to Lutheran faith.

The EASA emblem, which was adopted in 1990, is composed of a quartered shield; the lines that divide the shield form a knight's cross symbolising Christian faith; the top left and bottom right fields carry the seven stars from the coat of arms of Ungern-Sternbergs, and the top right and bottom left fields carry three lilies from the coat of arms of the von Lievens. Professor Unger himself interprets the stars (six-pointed stars as in the Solomon's Temple in Jerusalem, not five-pointed stars that inspired the French Revolution) to be symbols of metaphysics, and the lilies - the symbol of natural sciences. In the centre there is a big cross because, as he says, there cannot be science without a cross, without faith. According to him, blue is a night's color, color of the humanities, and gold symbolizes natural sciences. Thus, the emblem of the most prestigious EASA is made of the coats of arms of knights residing in Livonia.

From the very beginning of collaboration initially driven by Professor Unger, between the EASA, the LAS and institute "Eurolat", headed by J. Stradinš until 1998 (since then headed by academician M. Kūle and recently transformed into a virtual, unfinanced organization), took the form of small international discussions / symposiums which were held every 2-3 years. In recent years, we have held joint meetings of the LAS and EASA, which are sometimes named the EASA assemblies.

In 2001, a tradition to award EASA Latvian prizes was established and J. Stradinš made a proposal to name the prize after Professor F. Unger, namely "Felix Prize". Since then, the prize awarding ceremony is associated with a small scientific conference. The LAS and the EASA have hitherto co-organised the following scientific events: "Dialogue between Christianity and Secularism in Latvia" (1995), "National Identity and Vision of Europe" (1998), "Safety and Certainty" (2003), "Society between Past and Future: Ageing and Succession of Generations" (2006), "Higher Medical Education and Health Care Policy: Contemporary Challenges for Latvia" (2009). Those who have been honoured 
with the "Felix Prize" (the so-called "big prize") include the then President of Latvia, folklorist and psychologist V. Vīke-Freiberga (2001), philosopher M. Kūle (2003), philosopher V. Zariņš (2006) and physician J. Vētra (2009), and "small prizes" have been awarded to archeologist I. Ose, and philosopher I. Šuvajevs (2001), linguist D. Baltaiskalna-Joma and historian Ē. Jēkabsons (2003), ethnographer R. Blumberga and politologist A. Sprūds (2006), philosopher R. Bičevskis and physician A. Irmejs (2009). Each prize carries a monetary award: for the "big prize" it is 2500 Euros and for a "small prize" — 700 Euros. These events have attracted the academic community of Latvia and have been attended by eminent scientists, public persons, Latvian religious leaders, physicians, ministers and state presidents. Proceedings from two conferences have been published in the Annals of the European Academy of Sciences and Arts (1996, 2000).

The symposium on national identity and vision of Europe, in 1998, gathered 70 participants from six countries. Speeches were delivered by G. Meierovics, founder and honorary president of European movement in Latvia, R. Umblija and V. Birkavs, both ministers of the Republic of Latvia, Professor P. Tulviste, Rector of Tartu University, Professor L.E. Larsen, chairman of the Danish Council of Science and others. The symposium played a role in Latvia's preparation for accession to the European Union. The volume of the Annals, which contained full texts of the speeches in the English language, was printed in 1500 copies and delivered to prominent scientists and leading European politicians (members of the EASA).

The EASA is located in Salzburg - the city of Mozart and Paracelsus; it receives government subsidies, but it is not an
Austrian national academy of sciences, it is an independent, transnational academy.

During the past 10-20 years, the European Academy of Sciences and Arts has become an internationally recognised scientific institution which associates several small research units in Austria, Germany, Rumania (Transilvania) and Latvia, and several foundations in Germany, Austria and Switzerland lend support to the academy. The EASA holds visiting or jubilee sessions in many European countries (including regular sessions in Aachen dedicated to emperor Charles the Great), and awards prestigious prizes (Tolerance Prize). The authority and prestige of the academy comes, to a great extent, from F. Unger's distinctive personality, from his promptitude and seemingly inexhaustible creativity. Perhaps, he personifies the academy itself and builds it in rather a dissimilar from other academies of sciences in Europe. The mission of the EASA is different from the traditional mission of academies of sciences that includes advancement of research. This Academy mainly deals with the humanities, religion, history of arts, ethics and related disciplines, but it is also highly respectful to medicine, demography and global issues. It is with pleasure to be aware that professor F. Unger holds a particularly favourable attitude towards Latvia. We should derive benefit from this and popularise our science and arts in Europe and draw inspiration from "old" European culture.

At the festive plenary session of the EASA in Salzburg on 7 March 2010 Latvia was represented by the vice president of the LAS Tālavs Jundzis, who read the congratulatory address of the LAS signed by President J. Ekmanis and the chairman of the Senate J. Stradiňš, and also passed on a congratulation signed by the EASA protector V. Zatlers.

\section{EIROPAS ZINĀTNYU UN MĀKSLU AKADĒMIJA BALTIJĀ}

Sniegts pārskats par 1990. gadā Zalcburgā dibināto Eiropas Zinātnu un mākslu akadēmiju (EZMA, Academia Scientiarum et Artium Europaea) un tās samērā ciešo saistību ar Baltiju un jo īpaši - ar Latviju. Šīs akadēmijas dibinātāji bija kardināls, teoloǵijas doktors Francs Kēnigs, profesors Nikolajs Lobkovičs un profesors Fēlikss Ungers (dz. 1943) - austriešu kardioķirurgs, Vīnes universitātes absolvents un Zalcburgas Paracelza universitātes kardioḳirurǵijas klīnikas direkors, kura dzimtas saknes iesniedzas viduslaiku Livonijā. F. Ungera tiešs priekštecis ir lỉbiešu valdnieks Kaupo (von Lieven dzimtas tēvs), kura meita precējusies ar bruṇinieku Ungeru, kam piederēja Ogre un Madliena. Pēc Livonijas valsts bojāejas Ungeri nepārgāja luterticībā, bet palika uzticami katolicismam un atgriezās senču zemē Ungārijā, resp. Austrijā. Par piemiņu dzimtas vēsturei paša dibinātās akadēmijas (ko nereti neoficiāli dēvē par Ungera akadēmiju) emblēmā likts bruṇinieka krusts, von Lieven lillijas un Ungernu-Šternbergu zvaigznes. EZMA ir īpatnējs veidojums - ne tik daudz klasiska zinātņu akadēmija ar akcentu uz eksaktajām, fundamentālajām zinātnēm un pētniecību, cik Eiropas zinātnisko, reliǵisko, filozofisko pamatvērtỉbu sargpostenis, ar mērki strādāt Eiropas nākotnei, uzturēt vienotību daudzveidībā, veicināt zināšanas, starptautisko sadarbību un toleranci. Akadēmija veidojās ap 1990. gadu, laikmetā, kad krita mūris starp Eiropas austrumiem un rietumiem, sabruka „sociālistiskā nometne”, Padomju Savienība un Tito Dienvidslāvija, kad sākās arī katoḷu baznīcas modernizācija, tās dialogs ar zinātni un citām reliǵijām.

Pašreiz EZMA locekḷu skaits pārsniedz 1300, EZMA locekḷi pārstāv 58 pasaules valstis, viṇu vidū ir 28 Nobela prēmijas laureāti. EZMA locekḷi ir, piemēram, bijušais PSRS prezidents M. Gorbačovs un pašreizējais pāvests Benedictus XVI (1992. gadā ievēlēts kā kardināls J. Ratzingers). EZMA misija ir dot savu ieguldījumu Eiropas vienotības attīstīšanā, veicinot zināšanas, sadarbību un toleranci. Kā vienu no svarīgiem notikumiem ar sabiedrisku skanējumu var minēt EZMA izstrādāto Tolerances hartu, kuru EZMA iesniegusi ANO.

Ungera akadēmija bija viena no pirmajām ārzemju zinātņu akadēmijām, kas nodibināja oficiālus zinātniskus kontaktus ar Latvijas Zinātņu akadēmiju vēl pirms PSRS sabrukuma. 1993. gadā EZ̉MA nodibināja Rīgā Eiropas-Latvijas institūtu kultūras un zinātnes apmaiṇai „Eurolat” (pirmie kuratori - J. Stradiņš un U. Viesturs; zinātniskais sekretārs - Dr. M. Jākobsons, pašreiz - Dr. A. Draveniece). Pēc pirmo EZMA locekḷu ievēlēšanas 1993. g. tika izveidota EZMA Latvijas delegācija, kuru vada J. Stradiņš. Pavisam Ungera akadēmijā ir bijuši / ir 15 locekḷi - dažādu nozaru zinātnieki no Latvijas (J. Lielpēters, J. Stradiņ̌̌, U. Viesturs, J. Volkolākovs, E. Blūms, R. Kondratovičs, 
A. Caune, I. Knēts, M. Kūle, P. Zvidriňš, V. Kluša, J. Ekmanis, T. Millers, J. Vētra, P. Zvidrinšs, T. Jundzis). Par EZMA loceklịem 2010. gadā nominēti arī R. Lācis, I. Lancmanis un S. Naumovs. Savukārt F. Ungers ievēlēts par LZA ārzemju locekli (1992), promovēts par Rīgas Stradiņa universitātes goda doktoru (2003), saņēmis P. Stradiņa balvu par EZMA izveidošanu un tās sniegto atbalstu Latvijas zinātnei (2009).

Kopš 1993. gada Ungera akadēmija kopā ar LZA Latvijā regulāri rīko simpozijus par aktuālām zinātnes problēmām, 2001. gadā F. Ungers iedibināja EZMA Eiropas balvu un divas veicināšanas balvas Latvijas zinātniekiem. Tās neoficiāli dēvē par lielo Fēliksa balvu un mazajām Fēliksa balvām. Iztirzāta EZMA darbības stratēǵija, tās vieta Eiropas un Latvijas zinātnē, tās Latvijā sarīkoto simpoziju (1995, 1998, 2003, 2006, 2009) problemātika. 